\title{
不金 IMPLEMENTATION OF LOCAL ECONOMIC EMPOWERMENT STRATEGY (LEEDS) IN THE HEALTH AND EDUCATION SECTORS, AKWA IBOM STATE, NIGERIA- AN ASSESSMENT
}

\author{
Atairet Clifford Atairet \\ E-Mail Id: atairetatairet@yahoo.com \\ Department of Public Administration, Faculty of Management Sciences, Akwa Ibom State University, \\ Obio Akpa Campus, Oruk Anam L.G.A., Akwa Ibom State, Nigeria
}

\begin{abstract}
To the developing nations, development remains vital, and most government policies are geared towards improving the development level. As a developing nation, Nigeria, in an attempt to meet the million development goals, came up with NEEDS at the federal level, SEEDS at the state level, and LEEDS at the local government levels. In line with the national policy framework, the Akwa Ibom State government set up committees in all the Local Governments to bring up a local government development blueprint using the national and state framework for the local government areas. This paper seeks to assess the implementation of this policy framework in Akwa Ibom State. From the different sectors, health and education sectors were used for the study. The theoretical framework adopted for this study is the implementation theory. Data for the study were sourced from primary and secondary sources. Three local government Areas were randomly selected for the study. The finding indicates that there is a problem of continuity with some government policies. Also, the continuous operation of local government joint accounts, among others, affected the implementation of the policy. Accordingly, it recommended that local governments be granted autonomy so that they will not be an appendage of the state government, and effort should be made to encourage continuity in Government.
\end{abstract}

Keywords: Development, Education, Health, Policy, and Policy Implementation.

\section{INTRODUCTION}

As Africa's most populous country, Nigeria is pivotal to attaining the Millennium Development Goals. To a large extent, it is believed that if poverty issues are successfully addressed in Nigeria, it will significantly reduce Africa's poverty level as a whole. With this in mind, Nigeria took into cognisance the need for a new approach to development planning that will reduce poverty; accordingly, the Federal Government in September 2003 initiated a new development planning strategy through consultation. The strategy launched in May 2004 was tagged National Economic Empowerment and Development Strategy (NEEDS) to provide an honest and selfcritical assessment of poverty in Nigeria, its multifaceted factors, and the challenges confronting the nation and bring about development. In line with the federal structure, the concepts of State Economic Empowerment and Development Strategy (SEEDS) for the states. The National Planning Commission issued the framework for developing SEEDS as a manual titled "Government for Growth and Service." Many states drafted and published SEEDS based on the stated visions of their Government but taking into account the Millennium Development Goals (M.D.Gs). Similarly, the Local Economic Empowerment and Development Strategy (LEEDS) were formulated at the local government level.

All these were policy framework aimed at reducing poverty and developing Nigeria. Nigeria is indeed known for various development planning dating back the colonial era; however, there is little evidence that actual development has resulted from the many plans so far implemented. Poor management of natural and human resources has ensured that it has not been sustainable even where some progress was made. It is, however, pertinent to define policy implementation, refers to the process of converting financial, material, technical, and human inputs into an output - goods, and service.[1].[2] policy implementation refers to the activities carried out in the light of established policies.

Following a well-crafted framework, the LEEDS document was also drafted at various local government areas of Akwalbom State. On this note, this study seeks to assess the implementation of the policy in Akwa Ibom State. Since there are different sectors, the researcher chooses to investigate the implementation in the health and education sectors.

\subsection{Statements of the Problem}

Nigeria is good in the formulation of policies, but poor at implementation [3]. Comprehensive policies covering virtually all aspects of socio-economic life have always been made often at a very high cost. Such policies appear to be efficient, optimal, and appropriate only on paper. The record of Nigerian policy implementation is recognized as very poor. Policies designed to provide a solution to Nigeria's numerous problems have had little or no success [4]. Nigeria is faced with such problems as corruption, robbery; thuggery, kidnapping, and DOI Number: https://doi.org/10.30780/IJTRS.V05.I10.002

pg. 4 


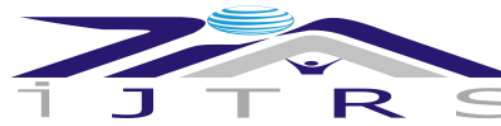

\section{International Journal of Technical Research \& Science}

cultism, among others are the security challenges Nigerian has to contend with while religious and ethnic violence is threatening the country's corporate existence [5]. It has been observed that policy implementation is one of the significant problems confronting developing nations. If all technicalities are Stripped, most developing nations' implementation problem is a widening gap between intentions and results. Implementation is vital during the planning and given the need attention, but most time, it is always taken for granted. Nonimplementation is almost becoming a norm in Nigeria. Could non-implementation of LEEDS in Akwa Ibom State be attributed to change of Government, lack of continuity of policies/agenda? Specifically, are their problems of LEEDS implementation in Akwa Ibom State; To what extent has the local Government succeeded in implementing LEEDS?

\subsection{Objectives of the Study}

The specific objectives of this study are to:

$>$ Determine the relationship between effective implementation of LEEDS and socio-economic development of Akwa Ibom State.

$>$ Ascertain the problems of LEEDS implementation in Akwa Ibom State.

$>$ Determine the extent to which the local Government succeeded in the implementation of the LEEDS programme.

\section{CONCEPTUAL EXPLICATION}

\subsection{Concept of Policy Implementation}

Implementation means just what Webster (dictionary) and Roget (thesaurus) say it does: to carry out, accomplish, fulfill, produce, complete [6]. A more precise definition is provided by[7]: "Policy implementation encompasses those actions by public or private individuals (or groups) that are directed at the achievement of objectives outlined in prior policy decisions." They make a clear distinction between the interrelated concepts of implementation, performance, impact, and stress. The observation is that impact studies typically ask, "What happened?" whereas implementation studies ask, "Why did it happen?" A widely accepted model of implementation's causal processes remains what [8] had called the "missing link" in social policy studies. It could be pointed out that: implementation research has been too restricted in time (i.e., an emphasis on crosssectional versus longitudinal analysis), too restricted in number (i.e., an emphasis on case study versus comparative analyses), too restricted in policy type (i.e., an emphasis on single policy type versus multiple policy types), too restricted in defining the concept of implementation (i.e., limited to a single output measure versus multiple measures), and too restricted in approach, i.e., the utilization of either "top-down" or "bottomup" approach versus both) the literature has come a long way in highlighting the inevitable complexity of the implementation process and the saliency of trying to understand this complexity.

Implementation inevitably takes different shapes and forms in different cultures and institutional settings. This point is particularly important in an era in which 'government' processes have been as transferred into 'governance' [9]. Implementation means carrying out, accomplishing, fulfilling, producing, or completing a given task. The founding fathers of implementation [6], define it as a relationship to the policy as laid down in official documents. According to them, policy implementation may be viewed as a process of interaction between the setting of goals and actions geared to achieve them [6]. Policy implementation encompasses those actions by public and private individuals or groups directed at achieving objectives outlined in policy decisions. These include both one-time efforts to transform decisions into operational terms and continuing efforts to achieve the large and small changes mandated by policy decisions [7].

[10] Defined policy implementation as what develops between the establishment of an apparent intention on the part of the Government to do something or stop doing something and the ultimate impact of the world of actions. As part of the policy cycle, policy implementation concerns how governments put policies into effect [11]. `Four main ingredients for effective implementation identified are: (1) specified tasks and objectives that accurately reflect the intent of policy; (2) a management plan that allocates tasks and performance standards to subunits; (3) an objective means of measuring subunit performance; and (4) a system of management controls and social sanctions sufficient to hold subordinates accountable for their performance. Failures of implementation are, by definition, lapses of planning, specification, and control [12].

Successful implementation requires compliance with statutes' directives and goals; achievement of specific success indicators; and improvement in the program's political climate [9]. Implementation is generally regarded as a vital and often neglected phase of strategic planning. Implementation encloses all actions that occur during the realization of the phase, i.e., budgeting infrastructure construction and the undertaking of necessary institutional changes for policy measures. Research into implementation has evolved for some decades now. The literature on implementation is arbitrary, unnecessary in any sequence, but particular highlights can be identified. Three generations of research into policy implementation exist. The first or classical generation of thinking on the subject began with the assumption that implementation would automatically happen once the appropriate policies had been authoritatively proclaimed. The second-generation set out to challenge this assumption, explain implementation 'failure' in specific cases and demonstrate that implementation was a political process no less complicated (and often more so) than policy formulation. The third or analytical 


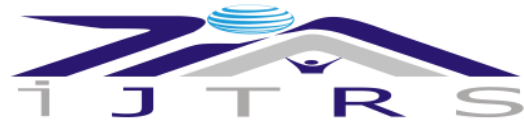

International Journal of Technical Research \& Science

generation, by contrast, has been less concerned with specific implementation failure and more with understanding how implementation works in general and how its prospects might be improved.

\subsection{Approaches to Implementation}

Varied opinions exist as to the most appropriate approaches to policy implementation in the South African context. Although various prominent paradigms are debated and practiced internationally, South Africans seemed to have adopted their approaches to executing the vast government policies. Naturally, the consequence is also varying degrees of success of policy implementation. It is noted that early scholars of policy science saw implementation merely as an administrative choice, which, once the policy had been legislated and the institutions mandated with administrative authority, would happen of and by itself. This view has, however, been debunked. While the complexity inherent in implementation processes has been performed, we are still nowhere near a widely accepted causal theory with predictive or prescriptive powers. Although the United States and Western Europe moved through different policy implementation phases, South Africa is currently in the implementation era. Scholars such as Wildavsky began implementation research in the 1960s and 1970s; however, standard theory is still lacking. There is still some confusion about when implementation begins when it ends, and how many implementation types there are. In the literature on policy implementation, several obstacles were identified in the way of successful policy implementation.

However, there is also a surprising number of common findings and suggestions between scholars of implementation literature. As implementation research evolved, two schools of thought developed to be the most effective method for studying and describing implementation: top-down and bottom-up. Top-down supporters see policy designers as the central actors and concentrate their attention on actors that can be manipulated at the national level. Bottom-up supporters emphasize target groups and service deliverers. Presently most theorist agrees that some convergence of the two perspectives exists. There is a close relationship between policy implementation and service delivery, which means that the top-down model's macro-level variables are tied with the micro-level bottom-uppers [13].

The most common meaning of implementation is carrying out, accomplishing, fulfilling, producing, or completing. This meaning could easily be equated with service delivery. For this paper's working definition, policy implementation is regarded as accomplishing policy objectives through the planning and programming of operations and projects to achieve agreed-upon outcomes and desired impacts.

\subsection{Local Economic Empowerment and Development Strategy (LEEDS)}

Although planning for development in Nigeria can be traced to the colonial era, its impact on sustainable development remains weak and unfelt. These have resulted in poor management of both the country's natural and human resources and little development. Thus, Nigeria remains a paradox of poverty amid massive oil windfall despite its rich human and natural resources.

In general, the livelihood opportunities of Nigerians have been reduced, exacerbated poverty and conflict. Considering the fact that Nigeria is Africa's most populous country, it has been stated that Africa's attainment of the Millennium Development Goals (M.D.Gs) depends on Nigeria's success in reducing poverty. To address underdevelopment problems, Nigeria requires a new and radical approach to development planning and poverty reduction if the prevailing high poverty rate is to be reduced. Thus, in recognition of the required drastic approach for meaningful development, the Government in September 2003 evolved a new development strategy for poverty reduction. This home-grown development strategy, known as the National Economic Empowerment and Development Strategy (NEEDS), was launched in May 2004. The NEEDS document provides an honest and self-critical assessment of poverty in Nigeria, its causes, and its challenges. [14]

The Federal Government of Nigeria launched the concept of State Economic Empowerment and Development Strategy (SEEDS) as the State counterparts to NEEDS. The National Planning Commission (N.P.C.) then issued a guidance manual entitled: SEEDS Framework- "Government for Growth and Service." Many states have now completed drafts of their strategies, and some have already published them. Both NEEDS and SEEDS were intended to be short-term policy frameworks that are designed to promote macroeconomic stability, improve the performance of the agricultural, manufacturing, solid minerals, and oil and gas sectors, improve the delivery of essential services, create an enabling environment for the private sector and invest in human capital towards reducing the poverty of the people.[14]

Their ultimate goals are poverty reduction, employment generation, and wealth creation. Following the successful launch of NEEDS and SEEDS at the Federal and State Government levels respectively, the challenge is to evolve similar development strategy documents at the Local Government level to be known as the Local Government Empowerment and Development Strategy (LEEDS). This challenge becomes more pertinent when the consensus that the formulation of NEEDS and SEEDS has not involved the grassroots population's participation. Nevertheless, most of the action programmes articulated in NEEDS and SEEDS target grassroots communities where poverty is pandemic. Ideally, most active programmes in NEEDS and SEEDS should have been conceived after the grassroots communities' input by articulating their LEEDS. It would have ensured the bottom-up planning principle rather than top-down planning that has dominated Nigeria's development planning. 


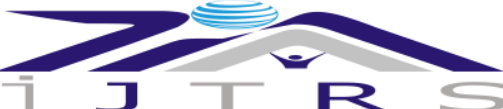 \\ 2.4 The Challenges of Preparing LEEDS}

Nigeria's constitution assigns specific national responsibilities to the Federal Government: defense, foreign affairs, etc. and assigns specific local issues to L.G.As, e.g., managing markets and primary education. However, there are many responsibilities carried out jointly by the Federal, State, and Local Governments. The way each level of Government is to carry out its responsibility in situations where the three levels of Government are evolved is not always well defined. Even where responsibility is assigned, such as primary education to the L.G. As State and Federal governments are often involved. The result is that there is no clear demarcation of roles for the different levels of Government, both between federal and state and between state and L.G.As.

The responsibilities for providing certain services are divided vaguely between all three tiers of Government. For example, road maintenance is divided between federal, state, and L.G.As. Besides, actions at one level an effect on the others. The overall success of NEEDS and SEEDS thus also depends upon the implementation of LEEDS. It may be an even more significant challenge than SEEDS. The States and F.C.T. were advised to encourage local government councils under their jurisdiction to also come up with their development strategies and programmes for the elimination of poverty.

Poverty cannot be eradicated without meaningful development efforts at the lowest level of governance, particularly at the grassroots level, where most of the population resides. LEEDS, therefore, focuses on development at the grassroots level involving critical stakeholders at the grassroots level. Within the framework of NEEDS and SEEDS, Local Government Economic Empowerment and Development Strategies (LEEDS) should be developed for the different L.G. As in Nigeria.

Consequently, the United Nations Development Programme (UNDP) commissioned the Centre for Population and Environmental Development (CPED) to coordinate the preparation of LEEDS in 12 Local Government Areas of six states (Adamawa, Akwa Ibom, Bauchi, Cross River, Kogi, and Ondo) entailing the participation of key stakeholders at the grassroots level. It is hoped that these will provide examples of how participation can be used to prepare LEEDS. Although it can be noted that the participatory approach has been used in aspects of planning in Nigeria, such as need/problem assessment, it is only in recent years that the challenges of integrating participation in all phases of planning have become noticeable. At present, participatory planning in Nigeria is still weak in planning issues encompassing human resources development, infrastructural development, finance, motoring, and evaluation.

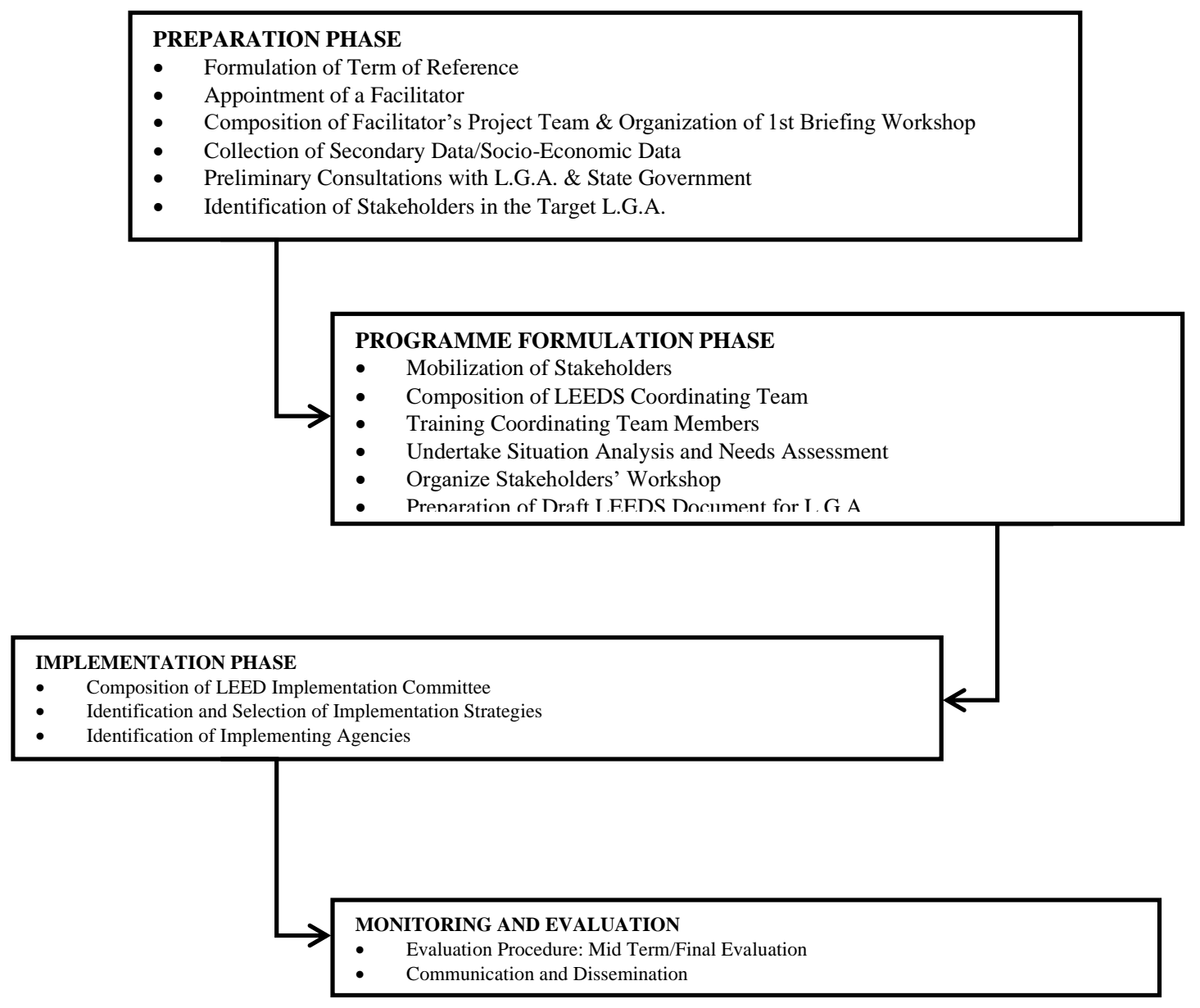

Source: Center for population and Environmental Development [15]

DOI Number: https://doi.org/10.30780/IJTRS.V05.I10.002

Fig. 2.1 Diagrammatic Representation of LEEDS Planning Process

WWW.ijtrs.com

Www.ijtrs.org 


\section{THEORETICAL FRAMEWORK}

The theoretical framework adopted for this study is the implementation theory. According [16], an implementation theorist, social choice rule represents the social objectives that the society or its representative wants to achieve. The theory needs to be understood from the outset as a process that is a continuous and interactive accomplishment - rather than an outcome. Some of the tenets of the theory are (i) social goals must be compatible with the incentive of the agents' incentive-compatible is a crucial requirement for the implementation theory to succeed, (ii) agents have to be informed about the state of the world (iii) in every state, the set of equilibrium outcomes have to equal the set of socially optimal outcome and (iv) A resource mechanism is essentially a system for communicating and processing information. The theory relies quite strongly on rationality.

The theory's primary claim is that the course of an implementation process is governed by the operation of social mechanisms that are energized and operationalized through agents' contributions. Implementation theory can answer whether LEEDS as a policy is implemented or not and can provide relevant information for how policies can be designed and implemented. As a theory, it helps us build a strong evidence base for all sectors in various contexts and provide guidance for policymakers and make us build innovative schemes. It is useful in understanding not only the choice of policy design elements but also the dynamics of policy continuity and policy change; it is base on these and others that the theory was adopted to guide the study.

\section{METHODOLOGY}

The study adopted a descriptive survey. Data were obtained from secondary and primary sources with limited quantitative. The secondary data were generated from books, journals, internet documents, and government publications (Specifically, LEEDS documents in the selected L.G.) in health and education. The primary data were sourced from the in-depth interview, focus group discussions (FGDs); key informant interviews were also supplemented with observation, which all serves as supporting data for the secondary data.

Three local Governments were randomly selected from the state's three senatorial districts, and they were Eastern Obolo, Nsit Atai, and Obot Akara Local Government Area. Data collection was carried out utilizing survey questionnaires, focus group discussions, informant interviews, observation, and documentation - review were recorded and transcribed. Youth groups, women groups, and religious organisations formed the focus group discussions while key informant groups comprise opinion leaders, former/present political office holders, chairman, and village councils' secretaries. Descriptive analysis was used to summarize, organize, and describe the data's essential features recorded by the researcher's assistant.

\section{PRESENTATION OF DATA/DISCUSSION}

Table-1.1 LEEDS Items for the Education Sector

\begin{tabular}{|c|c|c|}
\hline ObotAkara & Eastern Obolo & Nsit Atai, \\
\hline 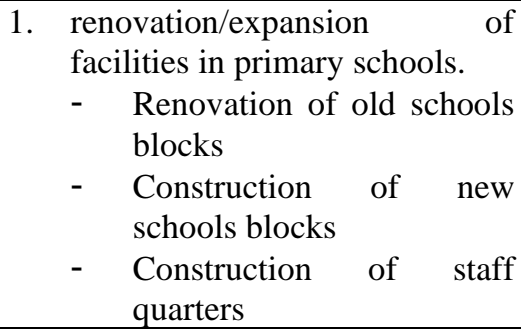 & $\begin{array}{l}\text { 1. Improving primary education } \\
\text { by the construction of } 10 \text { new } \\
\text { classrooms blocks }\end{array}$ & $\begin{array}{l}\text { 1. Registration and provision of } \\
\text { learning } \\
\text { materials/equipment in } \\
\text { nursery schools. }\end{array}$ \\
\hline $\begin{array}{l}\text { 2. Construction/equipping of } \\
\text { science and technology } \\
\text { laboratories in primary and } \\
\text { secondary schools. }\end{array}$ & 2. Rehab & $\begin{array}{l}\text { 2. Renovation of old blocks and } \\
\text { building of new blocks in } \\
\text { primary schools. }\end{array}$ \\
\hline $\begin{array}{l}\text { 3. Provision of instructional } \\
\text { materials for primary and } \\
\text { secondary schools. }\end{array}$ & $\begin{array}{l}\text { Renovation of existing } \\
\text { classrooms blocks }\end{array}$ & $\begin{array}{l}\text { 3. Renovation of secondary } \\
\text { schools and provision of } \\
\text { boarding facilities }\end{array}$ \\
\hline $\begin{array}{l}\text { 4. Provision of computers to } \\
\text { primary and secondary } \\
\text { schools/electricity in schools. }\end{array}$ & $\begin{array}{l}\text { 4. Improving secondary and } \\
\text { tertiary education in Eastern } \\
\text { Obolo }\end{array}$ & $\begin{array}{l}\text { 4. Building staff quarters in } \\
\text { selected primary and } \\
\text { secondary schools and } \\
\text { providing laboratory } \\
\text { equipment and other } \\
\text { facilities in schools. }\end{array}$ \\
\hline $\begin{array}{ll}5 . & \text { Establishing } \\
& \text { technical/vocational colleges }\end{array}$ & $\begin{array}{ll}\text { 6. Improving literacy level in } \\
\text { Eastern Obolo }\end{array}$ & $\begin{array}{l}\text { 5. Establishment of Technical } \\
\text { Colleges in the L.G.A. }\end{array}$ \\
\hline $\begin{array}{ll}\text { 5. } & \text { Migrant } \\
\text { Development } \\
\text { (MISDEP) }\end{array}$ & 6. Funding/Support to SUBED & $\begin{array}{l}\text { 6. Establishment of Adult } \\
\text { Training Institution in the } \\
\text { area }\end{array}$ \\
\hline
\end{tabular}




\begin{tabular}{|c|c|c|}
\hline 7. Student finance & $\begin{array}{lll}\text { 8. } & \begin{array}{l}\text { Encouraging } \\
\text { groups }\end{array} & \text { vulnerable } \\
\end{array}$ & $\begin{array}{l}\text { 7. Training of teachers at all } \\
\text { level of education }\end{array}$ \\
\hline 8. School sport development & 7. Establishing new schools & $\begin{array}{l}\text { 8. Award of scholarship to } \\
\text { secondary/tertiary school } \\
\text { students, especially girls, } \\
\text { with particular attention to } \\
\text { students studying } \\
\text { professional courses in the } \\
\text { university }\end{array}$ \\
\hline $\begin{array}{l}\text { 9. Adult Education Development } \\
\text { Project (ADEDEP) }\end{array}$ & $\begin{array}{l}\text { 9. The building of staff } \\
\text { quarters/schools }\end{array}$ & $\begin{array}{l}\text { 9. Educate parents on the need } \\
\text { to send their female children } \\
\text { to school. }\end{array}$ \\
\hline $\begin{array}{l}\text { 10. Capacity building/teachers } \\
\text { training }\end{array}$ & $\begin{array}{l}\text { 8. Educational empowerment } \\
\text { through scholarship and } \\
\text { bursary awards }\end{array}$ & \\
\hline 11. Central library project & $\begin{array}{l}\text { 9. } \begin{array}{l}\text { Educational awareness } \\
\text { (Advocacy programme) }\end{array}\end{array}$ & \\
\hline
\end{tabular}

Source: LEEDS documents Nsit Atai [17], LEEDS documents Eastern Obolo[18] and LEEDS documents Obot Akara [19] compiled by the researcher.

Table-1.2 LEEDS Item for the Health Sector

\begin{tabular}{|c|c|c|c|}
\hline \multicolumn{2}{|c|}{ NsitAtai } & \multirow{2}{*}{$\begin{array}{l}\text { Eastern Obolo } \\
\begin{array}{l}\text { 1. Building/renovation } \\
\text { equipping new/existing health } \\
\text { centres }\end{array}\end{array}$} & \multirow{2}{*}{$\begin{array}{l}\text { ObotAkara } \\
\text { 1. Rehabilitation/expansion of health } \\
\text { facilities at existing health } \\
\text { centres }\end{array}$} \\
\hline & $\begin{array}{l}\text { Renovation of all the } \\
\text { existing health centers } \\
\text { in the L.G.A. }\end{array}$ & & \\
\hline 2. & $\begin{array}{l}\text { Establishment of } 3 \\
\text { permanent structures } \\
\text { for the health centres } \\
\text { and health posts }\end{array}$ & $\begin{array}{l}\text { 2. Provision of essential drugs, } \\
\text { furniture, } \\
\text { personnel }\end{array}$ & $\begin{array}{l}\text { 2. Eradication of six killer diseases } \\
\text { among children }\end{array}$ \\
\hline 3. & $\begin{array}{l}\text { Establishment of } 3 \\
\text { new health centres at } \\
\text { ward } 3,6 \text { and } 10\end{array}$ & $\begin{array}{l}\text { 3. Construction of a general } \\
\text { hospital for Eastern Obolo L.G.A. }\end{array}$ & $\begin{array}{l}\text { 3. HIV/AIDS and other health } \\
\text { advocacy programmes }\end{array}$ \\
\hline 4. & $\begin{array}{l}\text { Provision of health } \\
\text { facilities/equipment } \\
\text { and drugs to all the } \\
\text { health centres }\end{array}$ & $\begin{array}{l}\text { 4. Public enlightenment campaign } \\
\text { and provision of drugs centers for } \\
\text { H.I.V./AIDS patients }\end{array}$ & $\begin{array}{l}\text { 4. Provision and distribution of } \\
\text { essential drugs and other } \\
\text { consumables }\end{array}$ \\
\hline & $\begin{array}{l}\text { Increase the numbers of } \\
\text { health personnel by } \\
70 \%\end{array}$ & $\begin{array}{l}\text { 5. Immunization against six (6) } \\
\text { killer diseases, i.e., Polio, measles, } \\
\text { diarrhea, chickenpox, etc. }\end{array}$ & $\begin{array}{l}\text { 5. Capacity building for health } \\
\text { service providers }\end{array}$ \\
\hline & $\begin{array}{l}\text { Capacity building of } \\
\text { health personnel in all } \\
\text { the centres }\end{array}$ & $\begin{array}{l}\text { 6. Provision of free health services } \\
\text { pregnant women, children, and } \\
\text { aged citizens. }\end{array}$ & $\begin{array}{l}\text { 6. Reduce maternal and infant } \\
\text { mortality rates }\end{array}$ \\
\hline & $\begin{array}{l}\text { Increase awareness on } \\
\text { H.I.V./AIDS }\end{array}$ & & 7. Equipping of the health facilities \\
\hline & $\begin{array}{l}\text { Improve the } \\
\text { nutritional status of } \\
\text { children to } 60 \%\end{array}$ & & \\
\hline & $\begin{array}{l}\text { Improve the nutritional } \\
\text { status of reproductive } \\
\text { age women to } 65 \%\end{array}$ & & \\
\hline
\end{tabular}

Source: LEEDS documents Nsit Atai [17], LEEDS documents Eastern Obolo[18] and LEEDS documents Obot Akara [19] compiled by the researcher.

\subsection{Discussion of Findings}

Due to the peculiarities of each Local Government Area in Akwa Ibom State, local government LEEDS drafting committees were set up to evolve/draft their LEEDS document. This became necessary to ensure that the Local government area articulates its peculiar development strategies in different sectors. These committees were duly trained in line with the SEEDS and NEEDS framework. The LEEDS document served as a document for expressing the social contract between the people and the Government for service delivery. Some key areas were infrastructural development, poverty reduction, wealth creation, employment generation, and value reorientation towards Government and entrepreneurship. The document was carefully drafted to ensure the 


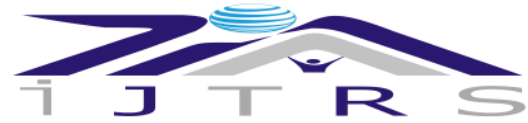

International Journal of Technical Research \& Science

attainment of these goals. The adopted strategies and the sectorial economic selection were carefully and harmoniously tailored to achieve early delivery.

The LEEDS document had the following strategic framework that would have made the implementation easy such as:

\subsubsection{Performance Target Strategy}

Highlights the key performance target and strategies towards realizing the LEEDS goals as a base for future action/programming and budget to guide implementation. The highlights attempted on sectorial bases.

\subsubsection{Strategic Implementation Plan}

This embodied plans on how LEEDS activities and achieve the target using the existing and propose institutions and programme highlighted under the strategic implementation plan. It was holistic, consistent, and persistent, as half measures yield not half result but often fail. Equally highlighted are tools, strategies, and instruments for implementation, implementation partners, and transparency in implementation.

\subsubsection{Approaches to Achieve Good Performance}

The document also take into account approaches to achieve good performance, and they include; increase/direct statutory allocation from Federation Account, matching grant scheme, reducing wasteful spending through the fiscal regime, expenditure-reduction imperative, monetization, management of treasury account, bureaucracy reforms and procurement reform; implementing institutional reforms through fiscal responsibility pack and strengthening of planning, research, and statistics (P.R.S.) department; capital market; renting/selling of asset; public-private partnership; improving external financing through foreign direct investment and official development assistance; improving/increasing in internally generated revenue and so on.

\subsubsection{Financing of LEEDS}

LEEDS were to be financed through internally generated revenue, statutory allocation from the federation account, Value Added Tax (V.A.T.), statutory allocation from the state, excess crude, stabilization funds, derivation funds, special grants including internal loans, external loans and funds from miscellaneous items.

\subsubsection{Monitoring and Evaluation}

The document also considers plans to monitor inputs/progress and evaluate output.[16],[17] and [18]

With all these strategies geared towards achieving a comprehensive policy covering virtually all aspects of social-economic life have always been made often at a very high cost. The policy appears to be efficient optimal only on paper confirming [3] assertion that.

Nigeria is reputed to be good on policy formulation; good on discussing ideas; good on making recommendations; goo on spending resources on printing policy documents; but very poor at implementing good ideas and policies. No wonder we remain under-developed amid abundant human, material, and natural resources.

The record of Nigerian policy implementation is recognized as very poor. This is the same situation with LEEDS implementation in Akwa Ibom State. In an oral interview with one of the respondents, the respondent maintained that during the period, it was political patronage to members of the committee, that Nigeria is noted for good policy formulation but very bad in implementation. The study also reveals that despite the policy that recommended direct allocation to the Local Government Area, which would have been useful to the implementation, the state government was still operating a joint account. By law, the State government was supposed to share its allocation to Local Government Areas, but this is not the case.

In Nsit Atai, the study reveals that in the area of health, there was some rehabilitation of dilapidated health centres and provision of health equipment and drugs, but much is not achieve in this direction as some many health posts are under staff, no capacity building for staff, lack of drugs in the health facilities. One of the respondents maintained that the method of acquiring drugs was not sustainable. Almost all the respondents in all the L.G.As said the same thing about facilities, drugs, and other medical consumables as not being enough. Most also confirm the inadequate furniture in the health facilities. As shown in the table of LEEDS developments above, the targets were spelled out, and the strategies of implementation stated, still not much was achieved. In Eastern Obolo within the period, the hospital in the document that was commissioned was started few years before the policy came on board though captured in the LEEDS document.

On immunization against the six killer diseases, all the respondents said that was achieved. The achievement in this sector may be since the federal Government and N.G.Os are mostly involved in its implementation. In the education sector, most respondent and groups maintained that renovation of schools classroom blocks was done in some schools, though handled by the state government through direct labour committee and not the local government councils. The findings also revealed that no scholarship was given to the students of the areas within the period, and there was no bursary payment as contained in the document for students of Tertiary institutions. Like Nsit Atai, it was proposed that 3 (three) technical colleges will be established in the area, but the Local Government Area established none. In Eastern Obolo, the proposal of building new classroom blocks by the Local Government Area was not made; some schools in the area do not have an adequate workforce for 


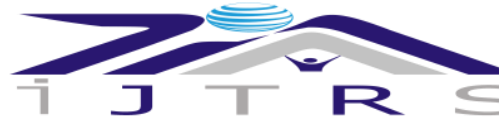

\section{International Journal of Technical Research \& Science}

the growing school intake occasioned by the state's free and compulsory education policy government. Almost all the respondents and groups confirmed that adult education is given lip service.

Consequently, it has been observed that policy implementation is one of the major problems confronting Nigeria. Stripped of all technicalities, the implementation problem in Nigeria, which Akwa Ibom State is part of, widens the gap between interactions and results. As noted by [20] who tried to identify the problem associated with policy implementation as the social carpenters and masons who fail to build to specification and distort the beautiful blueprint. Here Honadle was equating policy with a building plan. Quoting him, he said:

"Implementation is the nemesis of designers; it conjures up images of plans gone awry and of social carpenters and masons who fail to build to specifications, thereby distorting the beautiful blueprints for progress handed to them. It provokes memories of "good" ideas that did not work and places the blame on the second (and secondclass) member of the policy and administration team..."

The above quotation indicates the importance attached to policy implementation and those responsible for implementing these policies. It also shows that no matter how beautiful the blueprint of a programme is, a defective implementation will make the whole programme nonsense. Unfortunately, as described by Honadle above, the situation is what goes on in most developing countries, Nigeria inclusive. As stated by [1], implementation in these countries often turns out to be the graveyard of policy where the intentions of the designer of policies are often undermined by a constellation of powerful forces of politics and administration in cooperation with people. Little attention is paid to implementation despite the paperwork. Like the LEEDS document, yearly budgets would have been based on it until almost all the areas are touched, but the new administration will develop new programmes. The document contained the performance target strategy, strategic implementation plan, approaches to achieve good performance, and sources of findings, which constitute policy and monitoring and evaluation mechanisms. The state government also did not give the local Government the needed atmosphere to operate since they are still operating a joint account and supervising the local Government.

\section{RECOMMENDATIONS}

From the findings, the following recommendations are, at this moment, proffered.

$>$ Local Government should be constitutionally granted autonomy so that Local Government will not be an appendage of the state.

$>$ The state should give the statutory allocation of the state revenue to local Government as contained in the constitution.

$>$ There should be continuity of government programmes, irrespective of the change in administration and political party.

$>$ There should be proper monitoring and evaluation of all policies/programmes and not on papers.

\section{REFERENCES}

[1] Egonmwan, J. (1991). Public Policy Analysis: Concepts and Applications; Benin City. Ambik Press.

[2] Ademolekun, L. (1983) Public Administration: A Nigerian and Comparative Perspective Lagos. Longman.

[3] Onibokum, A. G. (1998). Implementation Strategies for the National Urban Development Policy for Nigeria. Paper presented at the National Workshop on the Modalities of Implementation of the National Urban Policy for Nigeria, Abuja.

[4] Ekaete, U. (2001) How We Run Nigeria, being the Excerpts from the Lecture delivered at the Senior Executive Course 23 at the National Institute for Policy and Strategic Studies, Kuru, Jos.

[5] Oshewolo, S. (2010) "Galloping Poverty in Nigeria: An Appraisal of the Governmental Interventionist Policies" Journal of Sustainable Development in Africa 12(6) pp. 271.

[6] Pressman, J. L., and Wildavsky, A. (1973), Implementation, Berkeley: University of California Press.

[7] Van, M. and Horn, V. (1975) "The Policy Implantation Process: A Conceptual Framework." Administration and Society, Vol. 6:4.

[8] Hargrove, E.C. (1975). The Missing Link: The Study of Implementation of Social Policy. Washington DC; Urban Institute.

[9] Hill, M. and P. Hupe (2002) Implementing Public Policy: Governance in Theory and Practice. London. Sage Publications.

[10] O Toole, L.J. (2000). Research on Policy Implementation. Assessment and Prospects. Journal of Public Administration Research and Theory, 19(2), 263-288.

[11] Howlett, M. and Ramesh, M. (2003) Studying Public Policy.Policy Cycles and Policy Subsystems. (2nd Edition) Oxford: Oxford University Press.

[12] Elmore, R. F. (1978) Backward Mapping: Implementation Research and Policy Decisions.The Academic of Political Science 94(4) pp. 601-616.

[13] Matlan (1995) Synthesizing the Implementation Literature: The Ambiguity-conflict Model of Policy Implementation. Journal of Public Administration Research and Theory, 5(2): 145-174.

[14] National Economic Empowerment and Development Strategy (NEEDS) 2008-2011 NEEDS-2 (Draft) National Planning Commission Nigeria. 
[15] Centre for Population and Environmental Development (CPED), 2010.

[16] Corchon, L.C. (2007). The Theory of Implementation: What did we learn: working papers, Department of Economics. Universidad Carlos III Madrid, Spain.

[17] Local Economic Empowerment and Development Strategy (LEEDS) 2008-2011, NsitAtai L.G.A. 2008.

[18] Local Economic Empowerment and Development Strategy (LEEDS) 2008-2011, Eastern Obolo L.G.A. 2008.

[19] Local Economic Empowerment and Development Strategy (LEEDS) 2008-2011, Abak L.G.A. 2008.

[20] Honadle, G. (1979) Implementation Analysis: The Case for an Early Dose of Realism in Development Administration. In International Development Administration: Implementation Analysis for Development Projects. Edited by G. Honadle and R. Klauss. New York: Pregar Publications. 